YI-WEN CHIEN AND SHARON A. DEVANEY

\title{
The Effects of Credit Attitude and Socioeconomic Factors on Credit Card and Installment Debt
}

\begin{abstract}
Most previous research on credit use has examined the effect of socioeconomic and attitude variables without considering the possible correlation among these factors. Also, the studies have not considered whether there is a difference between general and specific attitudes toward credit and the use of credit. This study addresses those problems and includes installment debt as well as credit card debt in the analysis. The study used data from the 1998 Survey of Consumer Finances. The findings show the higher the specific attitude index, the higher the outstanding credit card balances, and the more favorable the general attitude toward using credit, the higher the installment debt. The results suggest the need for greater awareness on the part of consumers and consumer educators on the influence of attitude in the use of credit.
\end{abstract}

Do consumers' attitudes toward credit influence their use of it? Many studies have concluded that the dramatic growth in credit use since the $1980 \mathrm{~s}$ is due, in fact, to the change in attitude toward credit (Canner and Cyrnak 1985; Godwin 1998; Norton 1993; Park 1993). Such a change in attitude implies that consumers are more willing to use credit to finance current consumption. Greater accessibility of credit (Bird, Hagstrom, and Wild 1997; Park 1993) or more knowledge about the benefits and risks involved in using credit (Kinsey and McAlister 1981) might account for the increased acceptability of credit. The widespread use of credit cards reflects consumer preference regarding prearranged lines of credit, and technological developments have made it much easier for creditors to offer revolving credit (Durkin 2000).

However, attitude might not necessarily predict behavior. Many studies in social psychology have found that attitude and behavior are not always compatible (Ajzen 1996). Sometimes a consumer's preference set is not equal to his or her choice set. For example, a consumer might like movie A rather than movie $\mathrm{B}$, but because of social or situational pres-

Yi-Wen Chien is Doctoral Candidate and Sharon A. DeVaney is Associate Professor, Department of Consumer Sciences and Retailing, Purdue University, West Lafayette, IN.

The Joumal of Consumer Affairs, Vol. 35, No. 1, 2001

0022-0078/0002-1 1.50/162

Copyright 2001 by The American Council on Consumer Interests 
sures, the consumer decides to see movie B anyway. Although the attitude-behavior relationship has been studied extensively in social psychology, the attitude-behavior relationship in consumer finance may be more complex. For instance, consumers might have favorable attitudes toward borrowing, but because they have lower incomes or poor credit histories, they may be credit constrained.

Another issue associated with credit use is whether or not attitude has a net effect on credit use. The net effect of attitude means the effect of attitude on credit use after the effects of other factors such as demographic and economic factors have been removed. Because attitude toward credit might be highly related to demographic and economic factors (Bird, Hagstrom, and Wild 1997; Danes and Hira 1990; Modigliani 1986; Zhu and Meeks 1994), it is possible that attitude could only mediate the effects of demographic or economic factors on credit use. In other words, attitude might not have a unique effect on credit use at all. For example, instead of a simple preference for borrowing, those who are in the early stages of their career might have more favorable attitudes toward borrowing because they expect to have more future resources to pay off their debts. Also, high-income consumers might have more favorable attitudes toward credit use because they are less likely to be credit constrained and have more ability to pay off their debts than low-income consumers. Thus, consumers with different demographic and economic characteristics might develop different attitudes toward credit use. If so, would attitude still have a unique influence on credit use, after the effects of demographic and economic factors on credit use have been removed?

Most studies have examined the effects of attitude along with demographic and economic variables on credit use without considering the possible correlation among the variables (Calem and Mester 1993; Canner and Cyrnak 1985; Lown and Ju 1992). This might cause bias due to multicollinearity. That is, even though the effect of attitude was reported as significant in previous studies, it could be because attitude mediated the effects of other factors on credit use and not because attitude alone affected credit use. There may be a difference between the measure of general attitude toward credit and attitude toward specific use of credit, and this has not been examined. Also, there is little research that considers both installment and noninstallment credit. This study examines these issues. The findings should contribute to a better understanding of consumers' attitudes toward using credit and their behavior where credit is involved. The literature review that follows includes sections on the relationship between attitude and behavior, types of consumer credit, demo- 
graphic and economic factors relating to credit attitude, and the relationship between credit attitude and credit use.

\section{REVIEW OF LITERATURE}

\section{Relationship between Attitude and Behavior}

Typically, people think attitude is positively related to behavior. That is, a more favorable attitude toward a specific behavior should lead to more occurrences of that behavior. However, some evidence for weak relations between attitude and behavior appearing in the 1930s motivated many researchers to question the assumption that attitude influences behavior (Ajzen and Fishbein 1977). Warneryd (1999) reported that the direct relationship between attitude and behavior was generally weak, partly because of differences in definition and measurement of attitude.

According to social psychology, there are at least three different kinds of attitude theories, and each of them proposes a different relationship between attitude and behavior. The theory of reasoned action proposed by Fishbein and Ajzen (1975) assumes that behavior can be predicted from attitude. The theory proposes that when people make choices, they form their attitudes based on their beliefs about the attributes of an object. In other words, people form a subjective probability to estimate the attributes of an object and then they weight their evaluations of those attributes along a dimension from good to bad.

Another theory is the cognitive dissonance theory proposed by Festinger (1957). It proposes that to reduce cognitive dissonance occurring when people's belief system and their behavior are not consistent, they tend to change or modify their belief system to make it able to account for their own behavior. In this case, the formation of attitude or belief is based on behavior.

In Krugman's (1965) hierarchy of effects, the relationship between attitude and behavior would differ depending on whether people have high or low involvement and whether the object is distinctive or not. If people have high involvement and the object is distinctive, behavior is based on attitude. But, if people have low involvement and the object is distinctive, attitude is based on behavior. If people have low involvement and the object is not distinctive, attitude and behavior are not related. An example of a distinctive object would be an automobile while a notebook is an example of an object that is not distinctive. 
Although each of these theories provides support for including attitude in a model to predict behavior, it is not feasible to develop this study based on theories because each theory specifies the measurement of variables that are not available to the investigators. Instead, the theories encouraged the inclusion of available information on attitudes and provide some insight for interpreting the results on the relationships between attitude toward credit use and credit-related behavior.

\section{Types of Consumer Credit}

The two major forms of consumer credit are installment and noninstallment credit. These forms can be exemplified by installment debt and credit card debt. With an installment loan, also known as closed-end credit, the amount borrowed must be repaid in a specific number of equal payments. With noninstallment, also known as open-ended credit, the credit is extended in advance of any transaction so that consumers do not have to reapply each time credit is desired. The amount owed can be repaid in full or through a series of equal or unequal payments, usually monthly. This type of credit includes bank credit cards, travel and entertainment accounts, service credit, and other charge accounts (Garman and Forgue 2000).

Sullivan, Warren, and Westbrook (2000) emphasize the differences between installment and noninstallment credit in greater depth. The credit decision is different. Although credit card issuers obtain information about consumers before issuing lines of credit, they make little attempt to review the borrower's financial status after the initial issuance of credit except to increase the credit limit. On the other hand, the credit decision for installment loans is likely to be more restricted, requiring more information from consumers and taking more time to process. Also, the borrowing decision is different. With installment loans, consumers make a decision to take on a large amount of debt, which could put their assets and future income at risk. In contrast, credit card debt itself is often incurred a relatively small amount at a time so consumers do not have to carefully assess their financial future at the moment of borrowing. In addition, the payment schedules are different. Credit card issuers often require a minimum monthly payment as low as $1 / 36$ or $1 / 48$ of the outstanding balance. A payment such as this is mathematically guaranteed to keep the user in debt for a long time (Garman and Forgue 2000).

When data on consumer credit use from the 1995 and 1998 Survey of Consumer Finances were compared, there appeared to be more change in the use of installment loans and very little change with credit card debt 
(Kennickell, Starr-McCluer, and Surette 2000). The percentage of families who had a bank-type credit card increased slightly from 66.5 percent in 1995 to 67.6 percent in 1998. Among families having balances outstanding on any of their credit cards, the median total balances owed by the family hardly changed over the period, standing at $\$ 1,700$ in 1998. In contrast, for those with installment loans, the median amount owed climbed 36 percent to $\$ 8,700$ in 1998 .

\section{Demographic and Economic Factors Relating to Credit Attitude}

According to the life-cycle hypothesis of saving (Modigliani 1986), consumers tend to maximize their utility by considering their life resources to smooth their lifetime consumption. Thus, younger consumers who have low current incomes relative to their future incomes are more willing to finance current consumption with their future income. According to the family resource management model (Lown and Ju 1992), demographic and economic variables would influence both credit attitude and credit practice. Then, demographic variables, economic variables, credit attitude, and credit practice would all influence financial satisfaction. Previous studies have shown a relationship between attitude toward credit use and age, income, and education (Bloom and Steen 1987; Mandell 1973). Upper-income consumers held more favorable attitudes toward credit cards than did lower-income consumers (Mathews and Slocum 1972; Slocum and Mathews 1970). Younger people had more favorable attitudes toward credit card use than older people (Awh and Waters 1974).

The relationship between attitude and the use of installment credit was investigated by Yieh (1996). Using the 1989 Survey of Consumer Finances, Yieh found that households headed by individuals who were either African American, female, married, and unemployed or those who were renters were more likely to have a negative attitude toward installment borrowing. The number of children was positively related to the probability of having negative attitudes toward installment debt. Further, the study showed that the probability of having a negative attitude toward installment debt declined when heads of households were younger, reaching the lowest point at age forty-three, and then increasing sharply.

\section{Relationship between Credit Attitude and Credit Use}

Households' amount of debt is influenced not only by their ability to borrow but also by their willingness to borrow (Godwin 1997). Accord- 
ing to Norton (1993), the dramatic increase in credit use from the $1930 \mathrm{~s}$ to the 1990s may be partly due to consumers' attitudes toward credit use. Credit has been deemed as more acceptable and accessible. Credit is even seen as an alternative form of income (Bird, Hagstrom, and Wild 1997; Norton 1993).

Danes and Hira (1990) investigated the relationship between knowledge, beliefs, and practices in the use of credit cards. They collected data during 1982 and found that the respondents who believed that credit cards should be used for installment reasons were inclined to use more credit cards and to accumulate finance charges more often. Respondents who were older and those with low incomes believed that credit cards should be used for convenience reasons.

Zhu and Meeks (1994) studied data on low-income families from the 1983 and 1986 Survey of Consumer Finances and tested the relationship among knowledge, attitude, and credit use. Their results showed that the significant determinants of the amount of credit outstanding in 1986 were age, employment status, credit balance in 1983, the interaction between specific attitude and education, and the interaction between specific attitude and debt balance in 1983. Namely, younger household heads and those employed full time had larger amounts of credit outstanding compared to households headed by someone who was older or not employed. The results showed an interactive effect of a higher education level and a more favorable specific attitude toward credit that contributed to a larger amount of credit outstanding in 1986. The authors suggested that welleducated consumers might have more need for using credit and more access to credit information. The finding that a larger credit balance in 1983 and a more favorable specific attitude contributed to a smaller amount of credit outstanding in 1986 was attributed to the need to be cautious about the amount of outstanding credit in spite of a more favorable attitude toward using credit.

Hayhoe, Leach, and Turner (1999) used ordered logistic regression to predict whether college students would hold a larger number of credit cards. A previously developed scale that measured attitude through questions on affective, cognitive, and behavioral factors was used in the study (Xiao, Noring, and Anderson 1995). Hayhoe et al.'s findings suggested that the following were significant predictors of holding more credit cards: affective and cognitive attitudes toward credit, gender, having taken a course in personal finance, borrowing from friends or relatives, the money retention attitude, use of money as a reward, and preparing a list before shopping. 
Canner and Cyrnak (1986) conducted a study to examine how attitude and some demographic factors as well as financial factors would affect the payment pattern for credit cards. They found that a generally favorable attitude toward borrowing was positively related to the use of credit cards as a source of revolving credit. Hayhoe, Leach, Turner, Bruin, and Lawrence (2000) found that affective credit attitude influenced credit card purchasing behavior among college students. Students with higher affective credit attitudes were more likely to purchase goods, such as clothes, electronic items, entertainment, travel, gasoline and auto repair, and food away from home, with credit cards. Calem and Mester (1993) found that general attitudes toward borrowing, as well as attitudes toward borrowing for some specific items, like a vacation trip and luxury goods, were positively related to consumer debt. Godwin (1998) reported a positive relationship between consumers' general attitudes toward using credit and the increase in consumer debt from 1983 to 1989 .

Davis and Lea (1995) used a pseudo-longitudinal design to examine the relationship between attitudes and debt. The regression analyses showed that there was a strong association between debt and attitudes toward debt. Davis and Lea raised the question of whether behavior had caused a change in attitude. They suggest that students may have realized that accumulating more debt was convenient and easy, and, as a result, they changed their attitudes. Yieh (1996) suggested that households' ability to incur debt and their attitude toward credit use contributed to the dramatic increase of consumer installment debt.

In summary, it is hypothesized that demographic, economic, and attitude factors will together influence credit use. Based on the theories and previous studies, it is hypothesized that there will be a negative relationship between age and credit use and that there will be a positive relationship between education, a general and specific credit attitude, and credit use. To assess whether attitude toward using credit has a unique effect on using credit after its mediation effect for demographic and economic factors is removed, a stepwise regression will be used to identify which factors have unique contributions on credit use. Because a large proportion of households do not have outstanding credit card balances or installment debt, researchers have employed tobit analysis to estimate the coefficients of the selected factors. 


\section{METHOD}

\section{Data and Sample}

Data were drawn from the 1998 Survey of Consumer Finances (SCF), which was sponsored by the Federal Reserve Board and collected by the National Opinion Research Center at the University of Chicago (Kennickell, Starr-McCluer, and Surette 2000). The SCF gathers information that includes demographic, human capital, financial, credit, employment, and retirement variables. The survey is conducted every three years. The 1998 SCF included 4,309 households. However, four observations were deleted for the public version. Thus, only 4,305 observations were released to the public in March 2000. The 1998 SCF contains five implicates to deal with missing and incomplete data; only the first implicate was used in this study. Descriptive statistics were weighted to represent the full population of the U.S.

\section{Dependent Variables}

Credit use was measured in two ways: the amount of installment loans and the amount of credit card debt. Installment loans included loans for education, cars, household appliances, hobby or recreational equipment, medical bills, property, home additions or improvements, loans from friends or relatives, loans for a business or investment, and other consumer loans. The components of installment loans were identified by the Federal Reserve Board when it provided an explanation for calculating net worth as part of the 1995 SCF codebook (Federal Reserve Board of Governors 2000). Credit card debt was the total outstanding balance on the credit cards that respondents were currently holding.

\section{Independent Variables}

The independent variables included demographic, economic, and attitude factors. Demographic factors included age, household size, ethnicity, marital status, professional status, and education. Economic factors included home ownership, the total annual income of the household, and liquid assets (including checking accounts, saving accounts, money market deposit accounts, money market mutual funds, and all accounts at brokerages). The definition of liquid assets was similar to the definition provided by the Federal Reserve Board in the 1995 SCF codebook. Atti- 
tude factors included general attitude and specific attitude toward using credit.

General attitude was measured in the SCF by asking respondents the following: "Do you think it is a good idea or a bad idea for people to buy things on the installment plan?" There were three possible responses: (1) good idea, (2) good in some way, bad in others, and (3) bad idea. People who answered "good idea" were categorized as having a favorable attitude toward credit use, people who answered "good in some way, bad in others" were categorized as having a neutral attitude, and people who answered "bad idea" were categorized as having an unfavorable attitude. Thus, general attitude included three categories: favorable, neutral, and unfavorable.

Specific attitude was measured by using respondents' answers to five dichotomous questions about their approval of borrowing money for someone like themselves for the following: a vacation trip, living expenses, fur coat or jewelry (used as a proxy for luxury goods), a car, and education expenses. The positive responses were summed to create a specific attitude index ranging from zero to five (approved of none or all of the specific uses of credit). Thus, the higher the specific attitude index, the more favorable the attitude toward credit. Coding of the independent variables is shown in Table 1.

\section{PROCEDURE}

Due to potential correlation among demographic, economic, and attitude factors, stepwise regression was used to identify which factors had a unique contribution on predicting credit use. The stepwise regression procedure is different from the all-possible-regressions procedure in that the stepwise regression procedure is an automatic search procedure that can develop the best subset of predictors (Neter, Kutner, Nachtsheim, and Wasserman 1996). Stepwise regression develops a sequence of regression models, at each step adding or deleting a predictor. In the present study, factors meeting the 0.15 significance level were added to the models, and the factors not meeting the 0.15 significance level were deleted from the models.

Then, tobit regression was used to estimate the coefficients of the selected predictors because a large proportion of the households had no installment loans ( 2,658 out of 4,305 households) or no outstanding balance on their credit cards ( 2,735 out of 4,305 households). The use of a linear function, such as ordinary least squares regression, leads to biased and inconsistent estimates of the coefficients when the dependent variable 
Table 1

Coding of Independent Variables

\begin{tabular}{lll}
\hline Variable & Definition & Coding \\
\hline Age & Age of household head & Continuous \\
Household size & Number in household & Continuous \\
Education & Number of years of education & Continuous \\
Caucasian & Ethnicity of household head & $1=$ yes; $0=$ no \\
Married & Household head is married & $1=$ yes; $0=$ no \\
Professional status & Head is professional or managerial & $1=$ yes; $0=$ no \\
Home ownership & Head has home ownership & $1=$ yes; $0=$ no \\
Log (income) & Log (annual household income) & Continuous \\
Liquid assets & Household liquid assets & Continuous \\
Favorable general attitude & General attitude toward using credit & $1=$ yes; $0=$ no \\
toward using credit & is favorable & $1=$ yes; $0=$ no \\
Neutral general attitude & General attitude toward using credit & is neutral \\
toward using credit & Specific attitude index toward using credit & Continuous \\
Specific credit attitude index & (ranging from 0 to 5) & \\
\hline
\end{tabular}

Note. General attitude toward using credit contains three categories: favorable, neutral, and unfavorable. Unfavorable general attitude toward using credit is used as a reference group.

is truncated (Maddala 1992). Analysis consisting of a stepwise regression followed by ordered logistic regression was conducted by Hayhoe et al. (1999). The procedure in this study was the use of stepwise regression to select a set of predictor variables followed by tobit to analyze the factors influencing the amount of consumer debt.

\section{RESULTS}

\section{Descriptive Statistics}

The characteristics of the sample are shown in Table 2. The average age of the household head was forty-nine years old and the average household size was between two and three persons. The average level of education that was attained by the head of household was thirteen years. Seventy-eight percent of the household heads were Caucasian and 52 percent of the household heads were married. One-quarter (24\%) had a professional or managerial occupation. Fifty-eight percent were homeowners. The average household income was $\$ 52,404$, and the average amount of liquid assets was $\$ 15,474$. About one-third held a general attitude toward credit that was favorable, one-third held a neutral attitude, and one-third held an unfavorable attitude. The specific attitude index was interpreted to mean that a higher number meant a more favorable atti- 
Table 2

Descriptive Statistics of Households in the 1998 Survey of Consumer Finances $(\mathrm{N}=4,305)$

\begin{tabular}{lcc}
\hline Characteristics & Mean & $\%$ \\
\hline Age & $48.7(17.3)$ & \\
Household size & $2.6(1.5)$ & \\
Education & $13(2.9)$ & 77.8 \\
Caucasian & & 52.4 \\
Married & & 24.3 \\
Professional status & & 58.3 \\
Home ownership & $52,404(229,784)$ & \\
Income & $15,474(124,440)$ & 28.9 \\
Liquid assets & & 37.6 \\
Favorable general attitude toward using credit & & 33.6 \\
Neutral general attitude toward using credit & & 8.1 \\
Unfavorable general attitude toward using credit & & 12.3 \\
Specific credit attitude index $=0$ & & 39.0 \\
Specific credit attitude index $=1$ & & 32.0 \\
Specific credit attitude index $=2$ & & 6.9 \\
Specific credit attitude index $=3$ & & 1.7 \\
Specific credit attitude index $=4$ & & \\
Specific credit attitude index $=5$ & & \\
\end{tabular}

tude toward using credit. In general, the frequency distribution of the specific attitude index was bell-shaped.

Further analysis was done on the relationship between the demographic and economic characteristics of the households and general attitude and specific attitude. ANOVA was used to analyze the mean differences, and Chi-square was used to analyze the percentage difference. All p-values were less than 0.001 . Table 3 shows the percentage of households with a favorable general attitude toward credit by demographic and economic characteristic, that is, age, education, income, and so forth. For example, if the household held a favorable attitude toward credit, the average age of the head of household was forty-five years. For households with an unfavorable attitude, the average age of the head of household was fifty years. Table 4 shows the mean or percentage of those who held favorable specific attitudes toward credit use. For example, the average age of head of household who did not approve of any of the specific uses of credit was sixty-two years, and the average age was forty-one years if the head of household approved of all five specific uses of credit.

In terms of general attitude as shown in Table 3, households with the following characteristics were more likely to hold favorable general attitudes toward using credit: households with a head who was younger, unmarried, 
Table 3

General Attitude toward Using Credit by Socioeconomic Factors in the 1998 Survey of Consumer Finances

\begin{tabular}{|c|c|c|c|c|c|c|}
\hline \multirow[b]{2}{*}{ Characteristics } & \multicolumn{2}{|c|}{ Favorable } & \multicolumn{2}{|c|}{ Average } & \multicolumn{2}{|c|}{ Unfavorable } \\
\hline & Mean & $\%$ & Mean & $\%$ & Mean & $\%$ \\
\hline Age & 45.4 & & 49.8 & & 50.3 & \\
\hline Household size & 2.7 & & 2.5 & & 2.6 & \\
\hline Education & 13.1 & & 13.1 & & 13.0 & \\
\hline Caucasian & & 75.0 & & 79.4 & & 78.5 \\
\hline Married & & 50.3 & & 53.8 & & 52.7 \\
\hline Professional status & & 25.4 & & 23.7 & & 23.9 \\
\hline Home ownership & & 51.2 & & 60.4 & & 62.0 \\
\hline Income & 52,808 & & 51,587 & & 52,969 & \\
\hline Liquid assets & 14,584 & & 15,705 & & 15,980 & \\
\hline
\end{tabular}

Note. ANOVA was used to analyze the mean differences. Chi-square was used to analyze the percentage differences. All p-values were less than 0.001 .

non-Caucasian, and in a professional or managerial occupation. Also, households with fewer liquid assets and without home ownership were more likely to hold a favorable general attitude toward using credit.

In terms of specific attitude as shown in Table 4, households with the following characteristics were more likely to have favorable specific attitudes toward using credit: households with a head who was younger, with more education, and in a professional or managerial occupation. Also, households with a larger household size were more likely to hold a larger number of favorable specific attitudes toward using credit. Income was positively related to favorable specific attitude. Liquid assets were negatively related to favorable specific attitude. These results suggest that households with more income will use credit for a larger number of specific purposes. Those with fewer liquid assets will use credit for a larger number of specific purposes.

\section{Determinants of Credit Use}

Credit use was measured by both installment loans and outstanding credit card balances. In the stepwise regression to select predictors of the amount of installment loans, education, marital status, professional status, home ownership, income, and favorable general attitude toward credit were selected as predictors at the 0.15 significance level. Because a large proportion of the respondents had no installment loans, researchers used the tobit model to estimate the coefficients of the selected predictors more 
Table 4

Specific Attitude Index (0-5) by Socioeconomic Factors in the 1998 Survey of Consumer Finances

\begin{tabular}{lcccccc}
\hline & $\begin{array}{c}0= \\
\text { least } \\
\text { favorable } \\
\text { Characteristics }\end{array}$ & 1 & 2 & 3 & 4 & $\begin{array}{c}5= \\
\text { most } \\
\text { favorable } \\
\text { (M or } \%)\end{array}$ \\
\hline Age & 62.1 & 56.5 & 48.8 & 44.4 & 40.9 & 40.9 \\
Household size & 2.1 & 2.3 & 2.7 & 2.7 & 2.7 & 3.1 \\
Education & 11.3 & 12.5 & 13.1 & 13.5 & 13.5 & 13.3 \\
Caucasian & $69.9 \%$ & $77.7 \%$ & $79.5 \%$ & $79.4 \%$ & $73.2 \%$ & $67.0 \%$ \\
Married & $42.7 \%$ & $53.4 \%$ & $56.3 \%$ & $51.6 \%$ & $44.9 \%$ & $50.0 \%$ \\
Professional status & $10.4 \%$ & $16.7 \%$ & $24.6 \%$ & $29.7 \%$ & $23.6 \%$ & $37.5 \%$ \\
Home ownership & $55.9 \%$ & $63.6 \%$ & $61.6 \%$ & $54.9 \%$ & $50.7 \%$ & $48.4 \%$ \\
Income & 38,475 & 52,983 & 53,798 & 53,460 & 54,424 & 54,764 \\
Liquid assets & 20,374 & 20,104 & 15,128 & 14,637 & 8,847 & 8,888 \\
\hline
\end{tabular}

Note. ANOVA was used to analyze the mean differences. Chi-square was used to analyze the percentage differences. All p-values were less than 0.001 .

Table 5

Determinants of Installment Loans in the 1998 Survey of Consumer Finances $(\mathrm{N}=4,257)$

\begin{tabular}{lcc}
\hline Variables & Parameter Estimate & P-value \\
\hline Education & 428.6055 & 0.8455 \\
Married & 36702.3855 & $0.0029^{* *}$ \\
Professional status & 33115.8117 & $0.0088^{* *}$ \\
Home ownership & -33875.1170 & $0.0061^{* *}$ \\
Log (income) & -4352.0000 & 0.3391 \\
Favorable general attitude toward using credit & 47938.2400 & $0.0001^{* * *}$ \\
Log Likelihood & -23918.4172 & \\
\hline
\end{tabular}

$* \mathrm{p}<0.05, * * \mathrm{p}<0.01, * * * \mathrm{p}<0.001$

accurately. Among the six factors in the tobit regression, four factors were significant at the 0.05 significance level. The results suggest that households headed by someone who was married, who was in a professional or managerial occupation, those who were renters, and those with a favorable general attitude toward credit would be more likely to have higher installment loans. The results are shown in Table 5.

In the stepwise regression to select predictors of outstanding credit card balances, household size, education, marital status, professional status, home ownership, income, and specific attitude toward credit were selected by the stepwise regression procedure as predictors at the 0.15 
Table 6

Determinants of Credit Card Debt in the 1998 Survey of Consumer Finances $(\mathrm{N}=4,257)$

\begin{tabular}{lcc}
\hline Variables & Parameter Estimate & P-value \\
\hline Household size & 645.1689 & $0.0001^{* * *}$ \\
Education & 309.0043 & $0.0011^{* *}$ \\
Married & 2342.7461 & $0.0001^{* * *}$ \\
Professional status & 1739.7155 & $0.0011^{* *}$ \\
Home ownership & 906.0954 & 0.0797 \\
Log (income) & -2031.0235 & $0.0001^{* * *}$ \\
Specific credit attitude index & 2123.8331 & $0.0001^{* * *}$ \\
Log likelihood & -18049.1155 & \\
\hline
\end{tabular}

${ }^{*} \mathrm{p}<0.05,{ }^{* *} \mathrm{p}<0.01, * * * \mathrm{p}<0.001$

significance level. Because a large proportion of the respondents had no credit card debt, the tobit model was used to estimate the coefficients of the selected predictors more accurately. Among the seven predictors, six predictors were significant at the 0.05 significance level. The findings show that households headed by someone who was married, who was in a professional or managerial occupation, with more education, with a larger household, with lower income, and favorable specific attitudes toward credit were more likely to have higher outstanding credit card balances. The results are shown in Table 6.

\section{CONCLUSIONS AND IMPLICATIONS}

Before discussing the contribution and implications of the study, some limitations are mentioned. First, the causality between attitude and behavior is uncertain. Although attitude is generally considered as a predictor of behavior, it is possible that behavior may predict attitude under some circumstances. In other words, although a more favorable attitude toward using credit can lead to a higher likelihood of using credit, a higher likelihood of using credit may also induce a more favorable attitude toward using credit. Because the data set is cross-sectional, the time order between attitude formation and credit use is unknown. Thus, the causality between credit attitude and credit use could not be examined. A second limitation may be the use of installment loans and the outstanding credit card balance as the measures of credit use. There may be other measures that could represent credit use. In the future, it may be possible to identify other measures of credit use. 
A contribution of this study was examining whether attitude toward using credit has a unique effect on behavior in regard to credit use. It was hypothesized that demographic, economic, and attitude factors could together influence credit use. In previous studies, the estimation bias resulting from the correlation among demographic, economic, and attitude was generally ignored. Due to the potential correlation among these factors, stepwise regression was employed to select the best set of predictors that had unique contributions on predicting credit use. Then, tobit analysis was used to estimate the coefficients of the selected predictors, as a large proportion of the households had no installment loans or credit card debt.

The results of the present study indicate that a favorable general attitude toward using credit has a positive effect on predicting the amount of installment loans, and favorable specific attitude toward using credit has a positive effect on predicting the amount of the credit card balance. This is consistent with the description of the differences between installment loans and credit card debt (Sullivan, Warren, and Westbrook 2000). Borrowing for an installment loan was described as a single decision to take on a large amount of debt with the commitment to make regular payments. Also, the installment loan involves the lender gathering more detailed information from the consumer and taking longer to process. The finding that general attitude toward credit is positively related to the amount of installment loan could suggest that this is an example of reasoned action (Fishbein and Ajzen 1975). It might also be an example of the hierarchy of effects (Krugman 1965) in which the consumer has more involvement and the object is distinctive or both. The purchase of a car on an installment loan could be an example of both consumer involvement and a distinctive object.

In contrast, it was the index for specific credit attitudes and not the general attitude toward credit that was positively related to the outstanding credit card balance. Referring to Sullivan, Warren, and Westbrook's (2000) statement that credit card debt is incurred a little at a time may be comparable to the cumulative effect of approval for the use of credit for one, two, three, four, or five specific items. If consumers believe that it is appropriate to purchase several different types of items or services on credit, that could increase the likelihood that they will carry a larger balance on their credit cards.

Also, when faced with their credit card balance, consumers can decide whether they will make a minimum payment, pay a larger amount, or pay in full. Although reasoned action (Fishbein and Ajzen 1975) may be a theoretical explanation for the relationship between specific attitudes and 
credit card balance, another possibility is the cognitive dissonance theory (Festinger 1957). The cognitive dissonance theory might be used to explain the apparent conflict that consumers might experience when they charge a product or service and receive immediate gratification although they know that the longer they delay paying the credit card balance, the more the goods or service will cost.

In addition to attitude, credit use was influenced by demographic and economic factors. Marital status and professional status were positively related to installment debt. But, home ownership was negatively related to installment debt. Education was positively related to credit card debt as hypothesized. Household size, marital status, and professional status were positively related to credit card debt. Income was negatively related to credit card debt.

These results should help consumers and consumer educators better understand the role of attitude toward using credit. Consumer educators should help consumers understand the importance of their attitudes toward credit if the consumers are attempting to change behavior resulting from charging too much or having difficulty in paying regularly and on time. Educators may need to help consumers distinguish between general and specific attitudes and to help them focus on the decisions involved in obtaining an installment loan or charging with a credit card.

If consumers believe that using credit for specific items is all right, they may be unable to change their behavior until they have changed their attitude. Consumer educators may need to involve consumers in behavior modification activities with a strong emphasis on attitude before a lasting effect can be achieved. Using generally accepted budgeting practices, such as setting goals, listing expenses, and developing a spending plan, may not work until the attitudes toward using credit have been identified and clients have examined their beliefs about attitudes. For example, reflecting on their early experiences with money, observing how their parents managed money, and talking with friends or their spouse about how decisions are made may help consumers understand their creditrelated behavior.

A public policy issue resulting from the study would be a better understanding of the motivation to use credit. Marketing on television, in the press, and on the Internet assumes that consumers want instant gratification. At the same time, consumer educators, financial advisors, and many others are encouraging consumers to save for long-term goals, such as funding a college education for their children or their own retirement. If consumers realized the actual cost of delaying payment on their credit 
cards, they might alter their behavior. Public awareness campaigns have had a desirable effect on other negative aspects of consumer behavior, such as smoking and not wearing seat belts, and this might be an opportunity for another positive behavioral change. If credit card issuers were required to include a sentence on consumers' monthly credit card statements about the length of time it would take to pay a bill if only the minimum payment is made, consumers might become more aware of the cost and change their behavior.

\section{REFERENCES}

Awh, Robert Y. and D. Waters. 1974. A Discriminant Analysis of Economic and Attitudinal Characteristics of Bank Charge Card Holders: A Case Study. Journal of Finance, 29, 3:973-80.

Ajzen, Icek. 1996. The Social Psychology of Decision Making. In Social Psychology: Handbook of Basic Principles, edited by E. Troy Higgins and Arie W. Kruglanski, New York: Guilford Press.

Ajzen, Icek and Martin Fishbein. 1977. Attitude-Behavior Relations: A Theoretical Analysis and Review of Empirical Research. Psychological Bulletin, 84: 888-918.

Bird, Edward J., Paul A. Hagstrom, and Robert Wild. 1997. Credit Cards and the Poor. Institute for Research on Poverty, Discussion Paper, No. 1148-97. Madison, W1: University of Wisconsin.

Bloom, David E. and Todd P. Steen. 1987. Living on Debt. American Demographics, 9, October: 22-3.

Calem, Paul S. and Loretta J. Mester. 1993. Search, Switching Costs, and the Stickiness of Credit Card Interest Rates, Federal Reserve Bank of Philadelphia, Working Paper 92-24/R, Philadelphia, PA: Federal Reserve Bank of Philadelphia.

Canner, Glenn B. and Anthony W. Cymak. 1985. Determinants of Consumer Credit Card Usage Patterns among U.S. Families. Journal of Retail Banking, 8: 9-18.

Danes, Sharon M. and Tahira K. Hira. 1990. Knowledge, Beliefs, and Practices in the Use of Credit Cards. Home Economics Research Journal, 18, 3: 223-35.

Davies, Emma and Stephen E. G. Lea. 1995. Student Attitudes to Student Debt. Journal of Economic Psychology, 16, 663-679.

Durkin, Thomas A. 2000. Credit Cards: Use and Consumer Attitudes. Federal Reserve Bulletin. 86, September, 623-634.

Federal Reserve Board of Governors. 2000. 1995 Survey of Consumer Finances Codebook. http://www.federalreserve.gov/pubs/oss/oss2/95/codebk95.txt. (December 2).

Festinger, Leon. 1957. A Theory of Cognitive Dissonance, Evanston, IL: Row, Peterson.

Fishbein, Martin and Icek Ajzen. 1975. Belief, Attitude, Intention, and Behavior: An Introduction to Theory and Research, Reading, MA: Addison-Wesley Publishing Co.

Garman, E. Thomas and Raymond E. Forgue. 2000. Personal Finance, Sixth Edition, Boston, MA: Houghton Mifflin Company.

Godwin, Deborah D. 1997. Dynamics of Households' Income, Debt, and Attitudes toward Credit, 1983-1989. The Journal of Consumer Affair, 31, 2; 303-25.

Godwin, Deborah D. 1998. Household Debt Quintiles: Explaining Changes 1983-1989. The Journal of Consumer Affairs, 32, 2: 369-93.

Hayhoe, Celia Ray, Lauren J. Leach, and Pamela R. Turner. 1999. Discriminating the Number of Credit Cards Held by College Students Using Credit and Money Attitudes. Journal of Economic Psychology, 20, 643-656.

Hayhoe, Celia Ray, Lauren J. Leach, Pamela R. Turner, Marilyn J. Bruin, and Frances C. Lawrence. 2000. Differences in Spending Habits and Credit Use of College Students. The Journal of Consumer Affairs, 34, 1: 113-33.

Kennickell, Arthur B., Martha Starr-McCluer, and Brian J. Surette. 2000. Recent Changes in U.S. Family Finances: Results from the 1998 Survey of Consumer Finances. Federal Reserve Bulletin, 86, January: 1-29. 
Kinsey, Jean and Ray McAlister. 1981. Consumer Knowledge of the Costs of Open-End Credit. The Journal of Consumer Affairs, 15, 2: 249-70.

Krugman, Herbert E. 1965. The Impact of Television Advertising: Learning without Involvement. Public Opinion Quarterly, 29, 3: 349-56.

Lown, Jean M. and In-Sook Ju. 1992. A Model of Credit Use and Financial Satisfaction. Financial Counseling and Planning, 3: 105-22.

Maddala, G. S. 1992. Introduction to Econometrics. New York: Macmillan.

Mandell, Lewis. 1973. Consumer Knowledge and Understanding of Consumer Credit. The Journal of Consumer Affairs, 7, 1: 23-26.

Mathews, H. Lee and John W. Slocum. 1972. A Rejoinder to Social Class or Income? Journal of Marketing, 36, 1: 69-70.

Modigliani, Franco. 1986. Life Cycle, Individual Thrift, and the Wealth of Nations. American Economic Review, 76: 297-313.

Neter, John, Michael H. Kutner, Christopher J. Nachtsheim, and William Wasserman. 1996. Applied Linear Statistical Models, Chicago, IL: Irwin.

Norton, Craig M. 1993. The Social Psychology of Credit. Credit World, 82, Sep/Oct: 18-22.

Park, Sangkyun. 1993. The Determinants of Consumer Installment Credit. Federal Reserve Bank of St. Louis, 75, 6: 23-38.

Slocum, John W. and H. Lee Mathews. 1970. Social Class and Income as Indicators of Consumer Credit Behavior. Journal of Marketing, 34, 2: 69-73.

Sullivan, Teresa A., Elizabeth Warren, and Jay Lawrence Westbrook. 2000. The Fragile Middle Class: Americans in Debt, New Haven, CN: Yale University Press.

Wameryd, Karl Erik. 1999. The Psychology of Saving, Cheltenham, U.K.: Edward Elgar Publishing Limited.

Xiao, Jing J., Franziska E., and Joan G. Anderson. 1995. College Students' Attitudes towards Credit Cards. Journal of Consumer Studies and Home Economics, 19, 155-174.

Yieh, Kaili. 1996. Who Has a Negative Attitude toward Installment Debt in the U.S.? Consumer Interests Annual, 42: 135-40.

Zhu, Lillian Y. and Carol B. Meeks. 1994. Effects of Low Income Families' Ability and Willingness to Use Consumer Credit on Subsequent Outstanding Credit Balances. The Journal of Consumer Affairs, 28, 2: 403-22. 